Structural Flaws in the Middle East Peace Process 


\section{International Political Economy Series}

General Editor: Timothy M. Shaw, Professor of Commonwealth Governance and Development, and Director of the Institute of Commonwealth Studies, School of Advanced Study, University of London.

Titles include:

Francis Adams, Satya Gupta and Kidane Mengisteab (editors)

GLOBALIZATION AND THE DILEMMAS OF THE STATE IN THE SOUTH

Susan Dicklitch

THE ELUSIVE PROMISE OF NGOS IN AFRICA

Lessons from Uganda

David Hulme and Michael Edwards (editors)

NGOs, STATES AND DONORS

Too Close for Comfort?

Staffan Lindberg and Árni Sverrisson (editors)

SOCIAL MOVEMENTS IN DEVELOPMENT

The Challenge of Globalization and Democratization

Laura Macdonald

SUPPORTING CIVIL SOCIETY

The Political Role of Non-Governmental Organizations in Central America

Kurt Mills

HUMAN RIGHTS IN THE EMERGING GLOBAL ORDER

A New Sovereignty

Michael G. Schechter (editor)

THE REVIVAL OF CIVIL SOCIETY

Global and Comparative Perspectives

J. W. Wright, Jr. (editor)

STRUCTURAL FLAWS IN THE MIDDLE EAST PEACE PROCESS

Historical Contexts

J.W. Wright, Jr. and Laura Drake (editors)

ECONOMIC AND POLITICAL IMPEDIMENTS TO MIDDLE EAST PEACE

Critical Questions and Alternative Scenarios

\section{International Political Economy Series \\ Series Standing Order ISBN 0-333-71708-2 hardcover \\ Series Standing Order ISBN 0-333-71110-6 paperback \\ (outside North America only)}

You can receive future titles in this series as they are published by placing a standing order. Please contact your bookseller or, in case of difficulty, write to us at the address below with your name and address, the title of the series and one of the ISBNs quoted above.

Customer Services Department, Macmillan Distribution Ltd, Houndmills, Basingstoke, Hampshire RG21 6XS, England 


\section{Structural Flaws in the Middle East Peace Process}

\section{Historical Contexts}

Edited by

J.W. Wright, Jr.

American Association for the Advancement of Science Overseas Diplomacy Fellow US Agency for International Development Mission

Cairo, Egypt 


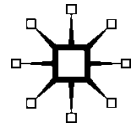

Selection, editorial matter and Chapter 7 ๑ J.W. Wright, Jr. 2002 Chapters 1-6, 8-12 @ Palgrave Publishers Ltd 2002

Softcover reprint of the hardcover 1st edition 2002 978-0-333-73850-4

All rights reserved. No reproduction, copy or transmission of this publication may be made without written permission.

No paragraph of this publication may be reproduced, copied or transmitted save with written permission or in accordance with the provisions of the Copyright, Designs and Patents Act 1988, or under the terms of any licence permitting limited copying issued by the Copyright Licensing Agency, 90 Tottenham Court Road, London W1T 4LP.

Any person who does any unauthorised act in relation to this publication may be liable to criminal prosecution and civil claims for damages.

The authors have asserted their rights to be identified as the authors of this work in accordance with the Copyright, Designs and Patents Act 1988.

First published 2002 by

\section{PALGRAVE}

Houndmills, Basingstoke, Hampshire RG21 6XS and 175 Fifth Avenue, New York, N. Y. 10010 Companies and representatives throughout the world

PALGRAVE is the new global academic imprint of St. Martin's Press LLC Scholarly and Reference Division and Palgrave Publishers Ltd (formerly Macmillan Press Ltd).

ISBN 978-1-349-40908-2

ISBN 978-1-4039-0770-7 (eBook)

DOI 10.1057/9781403907707

This book is printed on paper suitable for recycling and made from fully managed and sustained forest sources.

A catalogue record for this book is available from the British Library.

Library of Congress Cataloging-in-Publication Data Structural flaws in the Middle East peace process: historical contexts / edited by J.W. Wright.

p. cm. - (International political economy series) Includes bibliographical references (p.) and index.

1. Arab-Israeli conflict-1993—Peace. 2. Arab-Israeli conflict-1993-Economic aspects. I. Wright, J.W., 1962- II. Series.

DS119.76.S82 2001

956.05-dc21

$\begin{array}{llllllllll}10 & 9 & 8 & 7 & 6 & 5 & 4 & 3 & 2 & 1\end{array}$

$\begin{array}{llllllllll}11 & 10 & 09 & 08 & 07 & 06 & 05 & 04 & 03 & 02\end{array}$ 
To my grandfathers, who if alive would have enjoyed seeing this book, and to my grandmothers and their children and grandchildren, who surely will enjoy seeing it.

You are all very important to me. 
This page intentionally left blank 


\section{Contents}

List of Tables and Figures ix

Prolog by J. W. Wright, Jr. $\quad \mathrm{x}$

Acknowledgements Xvi

List of Abbreviations $\quad$ xvii

Notes on the Contributors xviii

Part I Commentaries: The Historical Context of the Middle East Peace Process

1 Twenty Years After Camp David:

Economic Diplomacy Gone Awry 3

Paul J. Findley

2 From Cold War to a Cold Peace: the Past and $\begin{array}{ll}\text { Future of the Middle East Peace Process } & 7\end{array}$

George Wilson

3 The Limiting Structure of Palestinian

Limited Self-Rule: Recent Historical Perspective

Fadle Naqib

Part II The Between-ness of the Palestinian Position

4 Between the Arms Race and Political Lobbyists:

How Pax Americana Threatens Middle East Peace

Stephen Zunes

5 Between Jordan and Israel: the Economics

of Palestine's Uneasy Triangle

Ishaq Diwan and Michael Walton

6 Between 'Supply Shocked' Markets:

the Case of Jordanian and Palestinian Returnees

Nora Ann Colton 
7 Between Israel and Saudi Arabia: Structural Dependencies in Labor and Finance J. W. Wright, Jr.

8 Between Desert Countries: the Political Economy of Water Under the Israeli Occupation of the Palestinian Territories and Beyond Alwyn R. Rouyer

9 Between Egypt and Jordan: Diverging Paths on Foreign Aid and Reform in the 1990s Bradley L. Glasser

10 Between the Palestinian Authority and Palestinian Civil Society: International Aid and the Peace Process Denis J. Sullivan

11 Between Hamas and the Palestinian Authority: Islamic Movements and Palestinian Development in the Gaza Strip Sara Roy

12 Between Capitalism and Jewish Voters:

Electoral Economics in Israel, 1977 to 1997

Shimson Bichler

Epilog by J. W. Wright, Jr. 


\section{List of Tables and Figures}

5.1 Strategic objectives of the three sides of the triangle 46

6.1 The 1990-1991 labor supply shock 74

6.2 Age profile of returnees versus non-returnees in Jordanian labor markets $\quad 77$

6.3 Jordanian employment by sector 78

$\begin{array}{ll}6.4 \text { Jordanian employment status } & 79\end{array}$

6.5 Occupational profile of interviewees 82

7.1 Saudi Arabia oil revenues, 1980 to 1989

7.2 Saudi Arabia revenues and expenditures, 1980 to $1989 \quad 103$

7.3 Jordanian remittances, 1964 to 1989

7.4 Jordanian remittances, 1990, 1991, 1992

8.1 Water consumption: Israel and the Palestinian Territories circa $1990 \quad 115$

8.2 Comparative water prices 124

9.1 The Jordanian central government budget of the 1990s: external vs internal revenues (\%) 139

10.1 Donor commitments to Palestinians in the West Bank and the Gaza Strip (US\$ 000) 156

10.2 Distribution of PNGOs by region 157

10.3 Palestinian socio-economic data, as of December 1994

10.4 EU Assistance to Palestinian NGOs in selected fields, in ECUs 170

10.5 Funding levels to Palestinians in the West Bank and the Gaza Strip, by type of donor (US\$) 172

10.6 Donor funding levels to selected sectors in the West Bank and the Gaza Strip (US\$) 


\section{Prolog}

J. W. Wright, Jr.

Structural Flaws in the Middle East Peace Process: Historical Contexts is the third in a series on the influences of trade and economics on the Middle East Peace Process. The chapters in these volumes contended that negligence in addressing, even considering, the economic impediments to Middle East Peace would lead to the Process's downfall. The other volumes are The Political Economy of Middle East Peace: the Impact of Competing Trade Agendas (Routledge, 1999), and Economic and Political Impediments to Middle East Peace: Critical Questions and Alternative Scenarios (with Laura Drake, Macmillan, 2000). These volumes grew from a thesis I developed during a Fulbright grant, which enabled me to study regional trade flows between the Gulf states and the Levant in order to see if they supported the Peace Process. It was a core assumption at the beginning of the Peace Process that market integration would facilitate economic and, by extension, political stability. I found that this assumption was fatally flawed and that as a result disintegration and not integration was occurring. However, I also found this situation was occurring for practical not political reasons.

The more hidden but more important conclusion that came out of this research was that the commercial and socio-economic structures that were developing out of the Peace Process's agreements and protocols were making the situation seriously worse. No attempt was being made to reduce the influence of lobbies that saw incentives for avoiding peace, few people were discussing impending financial crises in the Peace Process states, little attention was being paid to unemployment and underemployment, with a result that the risk of conflict was being raised.

In this volume we look back at the events over the last ten years and evaluate the structural and institutional mechanisms that have grown out of the Peace Process and analyze how they have led to its failures. What we find is that the inability to address commercial and economic issues, and the unwillingness to create fair trade regimes has not only disabled the process as a negotiating framework, it has created systemic and significantly weak social and economic structures that may prevent peace altogether; certainly they help to justify conflict. As we did when preparing the first two volumes, we hoped we would be proven wrong, but feared and still fear that indeed we were right. 
There is no doubt that in this first decade in a new century that approaches to Middle East peace will change. As I wrote this introduction, Secretary of State Colin Powell had just left the Gulf War's 10th Anniversary ceremonies and was on his way to meet the region's leaderships. He no doubt told them all that in George W. Bush's administration a new style of diplomacy was imminent and that there should be renewed hope about the prospects for peace. Of course in the back rooms the dialog was different - some of which I was in. There, people were less reticent about expressing their concerns about havoc Sharonian diplomacy might cause, about offensives Baghdad might led, about possible perils on the 'Arab street', about the need to diffuse the situation in southern Lebanon, and about just how long Yasser Arafat can hang on to his control of Gaza. (Many felt he had already lost control.) No one expected Egypt's position to change dramatically as long as there continues to be a massive transfers of taxpayer dollars from the United States to Egypt. The same is true for Jordan, although they receive much less aid.

The point we wish to make herein is that the Peace Process itself has created economic and political structures - some formal and some informal - that have in fact become sources of conflict and instability. What the new leaderships is Amman, Beirut, Damascus, Jerusalem and Washington do now will be inconsequential over time unless they address the structural flaws that exist at the Process's very foundation, e.g. the region's trade regimes and social-economic support systems are weak and they are being made weaker by the protocols themselves. Unknowingly - we will assume - the Clinton Administration's inconsistent 'brinksmanship' approach to the Peace Process undermined all sides' positions, even the US's, the result being wasted time and power vacuums in the West Bank and Gaza, increased resistance in both areas, short-term regimes and inconsistent leadership in Israel, and a general lack of strategy.

Speculation about what will come next will therefore yield little fruit unless it is based upon serious analysis of the structural biases new leaders in the Peace Process have inherited, and unless those biases are placed into appropriate historical contexts. This is what we wish to do in this collection of essays, aptly entitled Structural Flaws in the Middle East Peace Process: Historical Contexts. While the chapters herein and the themes they address are free-standing, they function as volume III for the two books mentioned above. In those we evaluated the critical trade and political-economic questions that faced negotiators and we tried to identify alternative scenarios wherein peace might be achieved. 
What has in fact happened was that we identified numerous regimes that put the Palestinians 'between' and not within structures that could enable them to address core issues. This 'between-ness' of the Palestinian situation makes their abilities to act as a state liminal, at best, and creates critical weaknesses in the Process that impede efforts toward peace. By evaluating historical contexts we provide the background needed to understand the real issues and begin repairing the faults.

Moreover, we review extant regional realities and compared them to current rhetoric in the Arab-Israeli Peace Process. There continues to be, of course, a great divide between the two. That said, it is from this rhetorical divide that we were able to identify incentives for maintaining the structures that keep the Peace Process weak. In this volume we try to more accurately identify these incentives and to investigate stakeholders' motives and influences for keeping prospects for peace at bay.

This approach also enabled us to correct false presumptions about events that have led to failure in the peace process. For example, literature has tended to view the Peace Process as an outcome of the Gulf War. There is no doubt that this military conflict set in motion a series of events that exposed the region's disparities and divisions more clearly than ever before. However, to see the Peace Process only as an outcome of the Gulf War is naïve. As Findley points out, the US role in peace negotiations predates the Camp David Accords, which were signed more than 20 years before the Gulf War. Furthermore, the economic and political structures in the Middle East that have changed in the 1990s find their roots in the 1970s and 1980s and would have occurred regardless of the Gulf War, albeit at a slower pace. For one thing, the fall of the Soviet block caused both leadership and funding voids throughout the region. For another thing, development achievements in the Gulf states caused dramatic shifts in the region's labor mobility and remittance structures. So, while we look at structures that developed since the Gulf War, placing them within historical contexts enables us to better discuss the real issues.

The collection is divided into two parts and contains 12 chapters. The first three chapters are commentaries that provide historical contexts by three leading figures who have been involved with the Middle East policy process for decades. Paul Findley was a US congressman who was intimately involved with US-Middle East affairs. George Wilson was an advisor to the White House during several administrations. Fadle Naquib is an academic who has worked closely with the United Nations' Conference on Trade and Development's Programme in support of the 
Palestinian People. In Chapter 1, Findley discusses the US's road to opening relations with the Palestinians and setting policy in subsequent years. Wilson (Chapter 2) discusses the role the fall of the Soviet Union played in building consensus for a Middle East peace process. Lastly in this part (Chapter 3) Naqib examines the strictures of occupation alongside the structures of 'limited self-rule' and illustrates just how unbalanced the process is and how limited PA autority really is.

The chapters that follow are research based and focus on the 'betweeness' of the Palestinian situation. In Chapter 4 Stephen Zunes looks at US lobbyists' roles in developing a 'Pax Americana'. He asserts that 'US policy is working contrary to ... a comprehensive settlement of the Arab-Israeli conflict.' His point is that the incentive structures faced by special interest groups 'make it doubtful that US policy in the Middle East will change until priorities at home are similarly redirected.'

Labor-oriented trade issues are examined in three chapters. Ishaq Diwan and Michael Walton look at the triangular trade arrangement that actually confines relations among Jordan, Israel, and Palestine. The Palestinains are in neither a geographically nor a politically enviable position. Nora Colton further illustrates the complexity of labor supply issues by describing the role of and attitudes toward returnees from the Gulf in the Jordanian economy. She emphasizes that the most immediate problem is employment. I tie the issues of labor mobility and financial liquidity together by detailing labor-remittance dependencies that have bound the Gulf states and the Levant since the 1970s.

Alwyn Rouyer (Chapter 8), however, convincingly argues that water rights may be the most vital issue to be resolved. Access to water is critical to improving living standards in the West Bank and Gaza while industrial development is also dependent on adequate water supply.

In Chapter 9, Bradley Glasser explores the nexus between foreign aid and political and economic liberalization. He asserts that Egypt in particular has been able to avoid making needed reforms because of its ability to secure exogenous resources through aid. In contrast, Jordan has pursued reforms and is better off for it.

Denis Sullivan's chapter on the use and misuse of aid funds in Palestine furthers Glasser's point. He examines ways in which the Palestinian Authority (PA) has re-directed funds meant to support NGOs. The PA's active campaign to co-opt and control traditional civil society organizations has had dire consequences, including a strengthening of support for groups like Hamas. Issues related to increased dependency on Islamic organizations are addressed by Sara Roy in Chapter 11. She shows how groups like Hamas use basic services, such as the provision of 
food, health care, and education, as means of gaining popular political support and even membership.

In Chapter 12, Shimson Bichler chronicles reactions Israeli voters have had, since 1977, to economically threatening situations. Just as Zunes notes that lobbyists and populists influence US elections, Bichler illustrates how the same happens in Israel. Unlike most articles on Israeli voting patterns, Bichler goes beyond the assumption that security issues dominate voters' agendas and analyzes the impact of perceived economic threats on voter behavior. He identifies a cycle of voter discontent over economics that forces regime changes.

I try to set a continuing dialog for commercial and economic analysis in place in the Epilog. Indeed, most of us agree that the policy vision over the last ten years was superficial and ill informed, maybe from the beginning but certainly throughout the Clinton Administration. Press conferences and personal agendas do not lead to peace and we should not have expected that they would. As I wrote in 1999 at the beginning of The Political Economy of Middle East Peace:

On October 24, 1998 the Washington Post called the accord 'a remarkable chapter of personal diplomacy' for Bill Clinton. President Clinton himself said that brokering the agreement was part to 'my job as a president, my mission as a Christian, and my personal journey of atonement.' On Face the Nation, Madeline Albright called this a 'personal political victory.' The important linkages here are that the spectacles through which the Clinton Administration is viewing the peace process are only personal and political, and not pragmatic or practical. ...thus, while the rhetoric alone may save the day - or at least serve to divert attention away from the day's other problems - it will not create peace. Both the politicians and the pundits seem to have, once again, missed the point.

The point being that without adequate address of key economic issues dysfunctional structures would evolve, and so they have. (Maybe it is all about the economy - stupid.) We can only hope that the George W. Bush Administration will avoid the personal publicity trap that has been set and offer instead a policy vision that is practical and that is based on pragmatic analyses of the region's true economic and political realities.

What evolves out of the chapters in this volume and its predecessors is certainty that huge economic resources and enormous political energies have been devoted to the Middle East peace process. But to what end? 
Over 30 years ago, in 1967, the occupation of additional Palestinian territories put into place new economic and political structures which would long leave the West Bank and Gaza behind in the development process. Ten years afterward, in 1977, the United States began its overt efforts toward brokering peace in the Middle East - an effort which set into place a structure of aid dependency that will not be easily changed. Ten years later, the Intifada further changed economic and political structures to the Palestinians' disadvantage. Ten years ago, the current Peace Process began without much apparent recognition of the effects the events ten, twenty, and thirty years earlier had on the region.

As a result, the Middle East Peace Process is riddled with structural flaws that are difficult but not impossible to repair. But we hope our words do not add unduly to feelings of despair about the prospects for peace. Rather, opportunities remain and we hope our contributions to the Process via these writings on its historical contexts will help facilitate the development of a fair and sustainable peace.

J. W. WRIGHT, JR. 


\section{Acknowledgements}

This collection has been through many phases, and at each stage of its production there are people whose efforts need to be acknowledged. All the contributors' efforts and patience are greatly appreciated. Sara Roy and Denis Sullivan deserve an extra note of thanks for reviewing all of our chapters and editing several of them. In addition, Anne Martin Holt's help has been very valuable during the final round of editing.

I want to thank the Council for the International Exchange of Scholars, and in particular Gary Garrison and Davis Adams. Without a Fulbright grant, I would not have been able to finish this text. Similarly, the USIS-Abu Dhabi staff - especially Jonathan Rice, Nadia Ibrahim, Attullah Hoshan, and Margaret Hamoud - greatly facilitated my work during my Fulbright year. The Jordanian-American Commission staff also provided assistance while I was working on this project in Amman.

Similarly, Mr Juma Al Majid and his staff at the Juma Al Majid Centre for Culture and Heritage, especially Drs Obaid Bin Butti and Fawzi Khoury, as well as Amal Al Fahmi, Bashar Qudah and Raed Qudah all provided much-needed assistance. I remember the Centre fondly.

Numerous others supported the project over time, sometimes by reading chapters and making comments and otherwise being generally supportive. Among them are Eugene Bird, Murial Crawford, Allen Douglas, Willie Fainsan, John Sherman Gideons, Nahla Kasrawi, Clyde Leamaster, Davy Mc Call, Fedwa Malti-Douglas, Allen Omoto, John Presley, Vicky Lynne Sawyer, Joanne Shams, Jaroslav Stetkevych, Suzanne Stetkevych, Qeisi Stetkevych, Khaled Stetkevych, Michael Stevensons, Mary Willis, Rodney Wilson, Valerie Yorke, and, most importantly, my parents, J. Wayne and M. Diane Wright, my grandparents and the rest of my family.

J. W. WRIGHT, JR. 


\section{List of Abbreviations}

$\begin{array}{ll}\text { AMF } & \text { Arab Monetary Fund } \\ \text { ACDA } & \text { Arms Control and Disarmament Agency } \\ \text { AHLC } & \text { Ad Hoc Liaison Committee } \\ \text { COPP } & \begin{array}{l}\text { Committee for International Assistance } \\ \text { to the Palestinian Police }\end{array} \\ \text { DOP } & \text { The Declaration of Principles } \\ \text { ESCWA } & \text { United Nations Economic and Social } \\ & \text { Commission for Western Asia } \\ \text { GDP } & \text { gross domestic product } \\ \text { GNP } & \text { gross national product } \\ \text { GCC } & \text { Gulf Cooperation Council } \\ \text { IFC } & \text { International Finance Corporation } \\ \text { IMF } & \text { International Monetary Fund } \\ \text { ICA } & \text { Israeli Civil Administration } \\ \text { IMA } & \text { Israeli Military Authority } \\ \text { IS } & \text { Israeli Shekel } \\ \text { JD } & \text { Jordanian Dinar } \\ \text { JSET } & \text { Joint Supervision and Enforcement Team } \\ \text { JWC } & \text { Joint Water Commission } \\ \text { MENA } & \text { Middle East and North Africa region } \\ \text { MERIP } & \text { Middle East Research and Information Project } \\ \text { NDP } & \text { National Democratic Party (Egypt) } \\ \text { NGO } & \text { Non-governmental organizations (usually registered) } \\ \text { NIS } & \text { New Israeli Shekel } \\ \text { PA } & \text { Palestinian Authority/Palestinian National Authority } \\ \text { PMA } & \text { Palestinian Monetary Authority } \\ \text { Protocol } & \text { Protocol on Economic Relations Between the } \\ & \text { Government of Israel and the PLO, representing the } \\ \text { UN } & \text { Palestinian People. Also referred to as the 'Paris Protocol' } \\ \text { UNCTAD } & \text { United Nations } \\ \text { UNDP } & \text { United Nations Commission on Trade and Development } \\ \text { UNRWA } & \text { United Nations Revelief and Works Agency } \\ \text { USIS } & \text { United States Information Service } \\ \text { VAT } & \text { value-added tax } \\ & \end{array}$




\section{Notes on the Contributors}

Shimson Bichler is a Professor of Political Science at Hebrew University, Mount Scopus, Jerusalem, Israel, where he teaches courses on political economics. His publications range from articles on the changing electoral process in Israel to studies on the political significance of structural adjustments in Israeli industry, especially as they relate to the country's core conglomerates. He has also written on Israeli privatization, and the economic policies of Labor and Likud in the peace process.

Nora Ann Colton is an Assistant Professor of International Economics at Drew University, Madison, New Jersey. Since receiving a doctorate from Oxford University, her work has focused on labor migration in the Middle East. She has conducted extensive fieldwork in Jordan, Egypt and Yemen. She has written numerous articles on economics within the Middle East. Her publications include Invisible Markets: The Informal Sector and Migration in Yemen.

Ishaq Diwan earned a PhD in economics from the University of California, Berkeley and has since worked with various divisions at the World Bank, including its Middle East Department, where he supervise research projects on the region and where he wrote on issues relating to Arab economic development, trade, and international and interregional finance. He has also writes on Middle East political-economic relations and is an active figure in programs relating to aid distribution in the West Bank and Gaza.

Paul J. Findley was a US Congressman from 1961 to 1983, served for 12 years as the senior Republican on the Middle East Subcommittee, and has served in various capacities with international organizations. He is a writer and a lecturer, and the author of two books on the Arab-Israeli dispute, the best seller, They Dare to Speak Out and Deliberate Deceptions. He is Chairman of the Council for the National Interest, a Washingtonbased membership organization that focuses on Middle East policy. He resides in Jacksonville, Illinois.

Bradley L. Glasser, after earning in $\mathrm{PhD}$ International Studies from Columbia University, won the 1995 Social Science Research Council's 
Ibn Khaldun prize for his dissertation, which also won the Andrew Wellington Cordier prize. Before that, he was Assistant Director of a Foundation devoted to Israeli-Palestinian Rapprochement. He teaches courses at the Columbia University Middle East Center, and continues to work on human rights issues facing people living in the West Bank and the Gaza Strip.

Fadle Naqib is a Professor of Economics at the University of Waterloo in Canada, where he specializes in research on commercial development in the Middle East. A consultant for the UN, he was the author of UNCTAD's 1995 report entitled 'Prospects for Sustained Development of the Palestinian Economy: Strategies and Policies for Reconstruction and Development'. His current research involves the development of econometric models which can be applied in Palestine.

Alwyn R. Rouyer is an Associate Professor of Political Science at the University of Idaho and specializes in Middle East politics and the politics of the Indian subcontinent. After earning an MA from Georgetown and a $\mathrm{PhD}$ from Tulane universities, he has been a Fulbright lecturer, a Joseph J. Malone Fellow, a Senior Fellow at the W. F. Albright Institute in Jerusalem, and a Visiting Scholar at Birzeit University in the West Bank in 1993. He is currently writing a book on the issue of water in the peace process.

Sara Roy is a research scholar at the Center for Middle Eastern Studies at Harvard University, where she received her PhD in political economics and international development studies. Dr Roy's work focuses on economic, political and social development in the Gaza Strip where she has lived and worked. She is the author of The Gaza Strip: The Political Economy of De-Development (Institute for Palestine Studies). Roy also acts as a consultant for various world aid organizations.

Denis J. Sullivan is Professor of Political Economy and Middle Eastern studies at Northeastern University in Boston, but has also served as the special assistant to the President, and is now a full professor. The author of numerous articles and editor of a collection published by Indiana University Press, he specializes in the analysis of the efficiency of international aid distributions programs. In addition, Dr Sullivan is a consultant to the World Bank and has worked with various NGOs. 
Michael Walton is a macroeconomics specialist who is a primary author for the International Bank for Reconstruction and Development's Multilateral Working Group on Economic Development. He contributed to the writing of their report on the West Bank and Gaza for Developing the Occupied Territory: an Investment in Peace, and he serves in various consulting capacities for World Bank projects and has worked as well for the European Union.

George Wilson received his doctorate from Cornell University in 1955, and has since served as an economics advisor to Presidents Kennedy, Johnson, and Nixon. Wilson has 145 publications to his credit, including several books and over 100 articles, predominantly on the subjects of transportation systems and, more recently, on global business patterns. He is currently a Distinguished Emeritus Professor of Business Economics and Public Policy, and a former Academic Dean at Indiana University, Bloomington.

J.W. Wright, Jr. serves as the Chief Trade Advisor for the US Agency for International Development's mission in Egypt and as a Overseas Diplomacy Fellow for the American Association for the Advancement of Science. He was formerly Head of Business Development for the Dubai Chamber of Commerce and Industry. In addition to work on the economics of Middle East peace, he writes on Business Development in Saudi Arabia (Macmillan, 1996) and Muslim Attitudes Toward Islamic Finance (International Journal of Islamic and Arabic Studies, 2000).

Stephen Zunes is an Associate Professor of Political Science at the University of San Francisco, and, previously, at the University of Puget Sound, Whitman College and Ithaca College, and served as Executive Director of the Institute for a New Middle East Policy, and held posts with the Institute for Global Policy Studies, the Institute for Policy Studies, and the US Institute for Peace. He is currently completing books on conflicts in the Western Sahara, and on US Middle East policy. 